\title{
Keputusan Hukum Izin Mengemudi bagi Perempuan Saudi Arabia Ditinjau dalam Perspektif Maqashid As-syari'ah
}

\section{Reza Bakhtiar Ramadhan}

Universitas Islam Negeri Sunan Kalijaga

Yogyakarta manmanna93@gmail.com

\section{Irham Shofwan}

Universitas Islam Negeri Sunan Kalijaga

Yogyakartairhamshofwan@gmail.com

\begin{abstract}
Abstrak
Tulisan ini mengkaji fatwa terbaru Saudi mengenai diperbolehkannya perempuan Saudi mengemudi dalam perspektif maqashid asy-syaria'ah. Uraian akan difokuskan pada hukum awal tentang larangan perempuan Saudi mengemudi hingga munculnya hukum diperbolehkannya perempuan Saudi mengemudi. Dalam proses perubahan hukum ini telah terjadi dialektika antara Umara' (kerajaan), Ulama (lembaga fatwa) dan Ummah. Tidak hanya berhenti sampai Di situ, peristiwa ini menunjukkan bahwa dalam urusan keagamaan Umara' (kerajaan) tetap memiliki otoritas yang melebihi lembaga fatwa. Bagi kita sudah jamak diketahui bahwa perempuan Saudi memiliki ruang gerak yang terbatas di ruang publik. Berbagai putusan hukum Saudi dinilai banyak merugikan kaum perempuan, tetapi kemudian kehadiran fatwa baru ini menjadi angin segar bagi perempuan Saudi. Akan tetapi perlu menjadi catatan bahwa kemunculan fatwa hukum diperbolehkannya perempuan Saudi mengemudi ini tetap mengacu pada maqashid as-syariah yang bertujuan untuk kemaslahatan manusia, dalam hal ini kaum perempuan Saudi di satu sisi, dan stabilitas negara di sisi lain.
\end{abstract}

Kata kunci: fatwa hukum, maqashid as-syariah, perempuan Saudi, lembaga fatwa. 


\begin{abstract}
This article examines Saudi's latest fatwa regarding the possibility of Saudi women driving in the perspective of maqashid asy-syaria'ah. The description will be focused on the preliminary law on the prohibition of Saudi women driving until the emergence of the law allowing women to drive. In the process, this law change has occurred dialectics between Umara' (kingdom), Ulama (fatwa institution) and Ummah. Not only stop there, this fact shows that Umara' (kingdom) in this case has authority over on fatwa institution. It is known for us that Saudi women have limited space in public space. Many Saudi law decisions are considered to be detrimental to women, but then the presence of this new fatwa becomes a breeze for Saudi women. But it should be noted that the emergence of legal fatwa of the Saudi woman driving this still refers to the maqashid as-syariah which aims to benefit humanity, especially Saudi women in one side, and nation stability in the other.
\end{abstract}

Keywords: fatwa law, maqashid as-syariah, Saudi woman, fatwa institution.

\section{Pendahuluan}

Fatwa hukum merupakan satu dari sekian banyak putusan hukum yang terlegitimasi. Dalam kajian hukum Islam, fatwa memiliki kedudukan yang sangat penting bagi suatu perkara/masalah yang belum ter-cover oleh putusan hukum (Al Haramain,1996: 18). Fatwa hukum merupakan produk ijtihad para mujtahid terhadap suatu perkara/ masalah. Dengan begitu, kita tidak dapat memungkiri bahwa ijtihadnya para mujtahid ini memiliki jasa yang sangat besar bahkan dominan. Tetapi patut dicatat juga, bahwa fatwa hukum itu sifatnya tidak mengikat dan hanya berlaku bagi madzab, aliran atau golongan tertentu saja. Dikarenakan setiap madzhab, aliran atau golongan memiliki cara yang berbeda dalam penggalian hukum. Seperti dalam kajian ushul fiqh, empat madzab besar fiqh; Syafi'iyyah, Hanafiyyah, Hambaliyyah dan Malikiyyah bersepakat bahwa dalam istinbath hukum mereka menggunakan 3 sumber hukum; Al-qur'an, Assunnah dan Ijma'(Abdul Wahab Khalaf, 1956: 15). Tetapi dari setiap madzab tersebut terdapat ikhtilaf (perbedaan) yang cukup menonjol dalam penggalian (istinbath) hukum. Sehingga produk hukum dan fatwa hukum yang dihasilkan pun berbeda. Contohnya, madzhab Syafi'iyyah lebih cenderung ber- 
istinbath dengan qiyas sebagai sumber hukum, ketika tidak diketemukannya dalil didalam Alqur'an, As-sunnah dan Ijma' mengenai suatu masalah. Lain halnya dengan madzhab Malikiyyah yang cenderung ber- istinbath dengan istihsan sebagai sumber hukum, ketika tidak diketemukannya dalil dalam Al-qu'ran, As-sunnah dan Ijma'(Abdul Wahab Khalaf, 1956:

20. Sehingga dari keterangan ini terdapat perbedaan mengenai karakteristik ber-istinbath hukum setiap madzhab, aliran dan golongan yang berkonsekuensi produk hukum atau fatwa hukum yang berbeda dan hanya akan dianut para muqallid (orang yang taklid kepada) madzab mereka masing-masing.

Hukum Islam sangat terkait dengan fatwa hukum, sebab hukum Islam merupakan bentuk legitimasi dari fatwa hukum. Ketika suatu lembaga otoritas fatwa telah mengeluarkan putusan hukum yang berupa fatwa dan telah disepakati oleh para ulama' yang terlegitimasi, maka secara otomatis fatwa tersebut sudah berlaku sebagai hukum. Adapun hukum Islam sering bersentuhan dengan kehidupan sosial - kemasyarakatan, karena hukum Islam memiliki dua fungsi. Pertama, sebagai hukum dan norma. Maksudnya, ia berusaha mengatur tingkah laku manusia sesuai dengan citra Islam. Sehingga, ia tidak terlepas dari pengaruh sosial budaya yang hidup di sekitarnya. Kedua, sebagai norma hukum yang memberikan legitimasi atau larangan-larangan dalam konteks spiritual (Tarmizi, 2012: 120). Selain dapat melegitimasi hukum, fatwa juga dapat berubah sesuai kebutuhan dan kondisi. Sebab produk hukum yang bernama fikih itu bersifat dzanniy (dugaan) dan ta'aqqul al- ma'na (dapat dilacak secara rasional) (Hazairin, 1974: 38). Dari sinilah kemudian kita dapat mengambil kesimpulan bahwa setiap fatwa hukum yang sudah terlegitimasi juga dapat berubah sesuai kebutuhan dan kondisi sosial - kemasyarakatan. Jika kita mengacu pada ilmu Ushul Fiqh, maka kita akan dihadapkan pada salah satu pembahasan mengenai an-nasikh wa al-mansukh (Al Haramain, 1996: 17), dimana dalil suatu hukum diganti dengan dalil suatu hukum yang lain dan yang berlaku adalah dalil hukum yang baru (pengganti). Menurut hemat kami, adanya pergantian hukum ini selain mengacu pada sosial kemasyarakatan juga mengacu pada ukuran maqashid asy-syariah yang mana dengan pergantian hukum 
tersebut ukuran kemaslahatannya lebih besar.

Di Saudi Arabia, fatwa hukum secara faktual memiliki posisi yang sangat sentral dan dominan. Karena secara kultural, politik dan struktural, di Saudi sejak dinasti Saud berkuasa secara kultural ke-

agamaan menganut pada paham Wahhabiyyah. Paham yang ber-afiliasi pada Muhammad Ibn Abdul Wahhab ini menjadi madzab resmi kerajaan Saudi. Sehingga seluruh elemen masyarakat Saudi seragam dalam hal pemahaman keagamaan. Dengan demikian sistem kultural pun terbangun dengan tanpa disadari. Juga, Saudi menyatakan dirinya sebagai negara dengan sistem kerajaan yang menggunakan hukum Islam sebagai undang-undangnya (bbc. com, 2017). Sehingga secara politik dan struktural Saudi sangat memperhatikan kedudukan fatwa, bahkan disana terdapat lembaga fatwa yang mengakomodir para ulama' Saudi didalamnya. Seperti Hai'ah Kibar al -Ulama' AsSu'udiyyah (Lembaga Ulama' Senior Saudi) yang merupakan lembaga- fatwa Saudi yang telah ada sejak tahun 1971 (wikipedia. org, 2017) . Lembaga fatwa ini membahas persoalan-persoalan keagamaan, sosial, kemasyarakatan dan sebagainya menurut kacamata hukum Islam. Ini, terlihat dari banyaknya hasil fatwa hukum yang telah diputuskan oleh Hai'ah Kibar al-Ulama' As-Su'udiyyah ini. Tidak terkecuali fatwa mengenai hukum perempuan Saudi mengemudi mobil. Adapun mengenai hukum ini terdapat dua fatwa yang berbeda, dalam waktu yang berbeda dan dalam keadaan sosial - masyarakat yang berbeda pula. Awalnya Hai'ah Kibar al-Ulama' As- Su'udiyyah berfatwa bahwa haram hukumnya bagi seorang perempuan bepergian dengan mengemudi mobil sendiri.

Dari kedua fatwa tersebut, menurut hemat kami, memiliki ukuran kemaslahatan yang berbeda. Jika ditinjau dari waktu, keadaan dan perkembangan sosial, ekonomi dan masyarakat akan tampak secercah petunjuk mengenai penasakh-an fatwa awal dengan yang terakhir. Dimana umara' (Pemerintah), ulama' dan ummah saling berdialektika mengenai fatwa hukum tersebut. Maqashid asysyari'ah sangat berperan dalam putusan fatwa-fatwa yang telah dilegitimasi oleh Pemerintah dan ulama' Saudi, terlebih mengenai hukum mengemudi bagi perempuan Saudi. Sehingga dalam tulisan ini muncul permasalahan yang layak 
untuk dibahas secara mendalam, yaitu: Pertama, bagaimana fatwa hukum mengenai haramnya mengemudi bagi perempuan Saudi menurut perspektif maqashid asysyari'ah ? Kedua, bagaimana fatwa hukum mengenai dibolehkannya mengemudi bagi perempuan Saudi menurut perspektif maqashid asysyariah dan apa efek dari fatwa hukum baru tersebut.

\section{Maqashid Asy-Syari'ah dan Produk Hukum}

Sebelum menuju kepada kajian fatwa mengemudi kendaraan bagi kaum perempuan di Saudi Arabia, terlebih dahulu diuraikan secara ringkas mengenai maqashid asysyari'ah dan kaitannya dengan produk hukum. Secara terminologis, maqashid asy-syari'ah

- sebagaimana definisi Wahbah alZuhaili, yang dikutip oleh Ghofar Shidiq - mengandung pengertian: makna-makna dan tujuan-tujuan yang dipelihara oleh syara' dalam seluruh hukumnya atau sebagian besar hukumnya, atau tujuan akhir dari syari'at dan rahasia-rahasia yang diletakkan oleh syara' pada setiap hukumnya (Ghofar Shidiq, 2009: 119).

Lebih spesifik lagi, Muhammad Said Ramadhan Al-Buthi mendefinisikan maqashid as- syari'ah sebagai manfaat yang dituju oleh Syari' (Pencipta syari'ah) yang Bijaksana untuk para hamba-Nya untuk menjaga agama, jiwa, akal, keturunan dan harta mereka, menurut urutan tertentu diantara lima hal tersebut (Al Buthy, 2014: 37).

Dari pengertian ini, dapat tergambar bahwa apa yang ditetapkan oleh Syari' sebenarnya mengandung tujuan baik untuk manusia, dimana tujuan baik tersebut merupakan makna yang bisa dipahami oleh akal, dan karenanya bisa menjadi bagian penting dalam memahami hukumhukum syari'ah yang telah tertulis, dan juga menjadi modal manusia untuk merumuskan produk hukum yang belum tertuliskan dalam ketetapan Syari'.

Dengan kata lain, maqashid asy-syari'ah mengandung dua hal, dimana dua hal ini merupakan kebaikan bagi manusia yang dituju oleh syari'ah, yaitu:

1. Mewujudkan manfaat, yakni segala kebaikan dan kesenangan bagi manusia yang diistilahkan sebagai jalb almanfa'ah (meraih manfaat).

2. Menghindari kerusakan, diistilahkan sebagai dar' almafsadah (menolak kerusakan). 
Dua hal ini kemudian diukur dengan standar kebutuhan dasar manusia, dimana batasan apa yang manfaat dan apa yang merusak ditentukan oleh seberapa besar pengaruh keduanya dalam kebutuhan primer, sekunder dan tersier manusia (Ghofar Shidiq, 2009: 121). Maka, produk hukum baik yang telah tertulis secara terang (sharih) dalam teks (nash) selalu mengandung maksud dan tujuan tersebut. Dan dalam merumuskan sebuah produk hukum, khususnya dalam kasuskasus kontemporer yang belum tertulis secara terang didalam nash, maqashid asy-syari'ah juga harus menjadi rasionalitas hukumnya.

Dalam kajian hukum Islam, maqashid asy-syari'ah menjadi perspektif yang sesuai untuk menelaah fatwa yang sedang hangat diperbincangkan di Saudi Arabia itu. Sebab, pertama, persoalan ini mengandung peralihan hukum dari dilarang menjadi dibolehkan. Awalnya wanita dilarang mengemudi kendaraan, kemudian produk hukum ini di nasakh menjadi dibolehkan. Tentu ada logika tertentu yang bisa diukur di balik eralihan ini, dan logika tersebut tidak keluar dari wilayah maqashid asy-syari'ah. Lalu yang kedua, hukum mengemudi bagi wanita Saudi Arabia oleh otoritas negara setempat, baik pemerintah maupun ulama', dilandaskan pada latarbelakang jalb al-mashalih (meraih kemanfaatan) dan dar' almafasid (mencegah bahaya). Dua hal ini menjadi elemen penting dalam kandungan makna maqashid asy-syari'ah.

\section{Larangan}

\section{Perempuan}

\section{Mengemudi Kendaraan}

Boleh dikatakan fatwa pelarangan mengemudi bagi kaum perempuan dari otoritas negara di Saudi Arabia merupakan fatwa yang dibangun dari sudut pandang "syari'ah adalah kemaslahatan", as-syari'ah maslahah (Ahmad Ar Raisuni, 2000: 29). Sudut pandang ini memuat berbagai komposisi hukum yang menyatakan, diantaranya:

- Syari'ah ada untuk merealisasikan manfaat dan menolak kerusakan.

- Syari'ah merupakan manfaat dan penolakan (bahaya).

- Syari'ah ada untuk merealisasikan manfaat dan membudidayakannya, dan menolak kerusakan dan mereduksinya.

- Syariah diciptakan untuk kemaslahatan-kemaslahatan pada hamba di dunia maupun di akherat. 
Sudut pandang ini bisa dibaca dari komposisi fatwa yang diproduksi oleh otoritas Saudi Arabia, yakni dari lembaga Hai'ah Kibar al-Ulama' pada tahun 1990 (aljazeera.net, 2017). Lembaga Ulama Senior itu menerbitkan fatwa pelarangan wanita mengemudi kendaraan, karena hal itu tidak sesuai dengan syari'ah. Pelarangan itu didasarkan kepada dalil-dalil dari Al-Quran dan Hadis-hadis Nabi Saw.. Diantara penggalan teks fatwa berbunyi:

"Seperti yang sudah dimaklumi bersama, tindakan mengendarai mobil yang dilakukan oleh wanita itu hanya akan menimbulkan dampak negative, yang notabene pasti juga diketahui oleh pihak-pihak yang menyerukan hal itu. Diantara dampak negatif tersebut adalah timbulnya tindakan khalwat yang diharamkan, melakukan perjalanan jauh, berbaur dengan lelaki tanpa ada yang melarang dan melakukan praktek terlarang yang mendasari pelarangan semua tindakan yang disebutkan sebelumnya, sementara agama yang suci ini telah melarang seтиa hal yang akan mengarah kepada tindakan haram, bahkan mengharamkannya. Oleh sebab itulah Allah menyuruh para isteri Rasulullah dan isteri orang-orang mukmin untuk tetap berada di rumah, menutup aurat, dan untuk tidak mempertontonkan perhiasannya pada yang bukan muhrim, karena semua itu akan mengarah kepada paham serba boleh yang merusak masyarakat" (binbaz. org.sa, 2017).

Dalam fatwa itu, pelarangan mengemudi didasarkan pada alasanalasan yang telah disebutkan secara sharih dalam dalil-dalil pokok yang melandasinya, meski- pun dalam perspektif fikih pemahaman terhadap alasan-alasan tersebut masih bisa diperdebatkan. Dalil pokok dari Al-qur'an yang melandasi fatwa tersebut antara lain:

"Dan hendaklah kamu tetap dirumahmu dan janganlah kamu berhias dan bertingkah laku seperti orang-orang Jahiliyyah yang dahulu dan dirikanlah solat, tunaikanlah zakat, dan taatilah Allah dan Rasulnya." (QS. Al-Ahzab: 33)

"Hai Nabi, katakanlah kepada istri-istrimu, anak-anak perempuanmu,- dan istri-istri orang mukmin, hendaklah mereka mengulurkan jilbabnya ke seluruh tubuh mereka. Yang demikian itu supaya mereka lebih mudah untuk dikenal, karena itu mereka tidak diganggu." (QS. Al-Ahzab: 59)

"Katakanlah kepada wanita yang beriman, hendaklah mereka menahan pandangannya dan 
memelihara kemaluan, dan dan perilaku ber-khalwah. Alasan janganlah- mereka menampakkan perhiasannya, kecuali yang (biasa) Nampak daripadanya. Dan hendaklah- mereka menutupkan kain kerudung ke dadanya, dan janganlah menampakkan perhiasannya, kecuali kepada suami mereka, atau ayah mereka, atau ayah suami mereka, atau putraputra mereka, atau putra-putra suami mereka ..." (QS. An-Nur: 31)

Adapun dalil-dalil dan Hadis Nabi Saw. yang disebutkan antara lain:

Dari Usamah ibn Zaid, Nabi Saw. bersabda: "Tidaklah aku tinggalkan fitnah yang lebih berbahaya untuk kaum laki-laki daripada kaum perempuan." (HR. Al-Bukhari, hadis nomor 5096)

Nabi Saw. bersabda: "Tidaklah seorang laki-laki berkhalwat dengan seorang perempuan kecuali pasti syaitan yang menjadi ketiganya." (HR. Ahmad)

Baik dalil dari Al-qur'an maupun Hadis di atas, menunjukkan bahwa rasionalitas dari alasan pelarangan mengemudi telah terkandung dengan jelas di dalam narasi dalil, yakni bahwa bahayanya adalah melanggar perintah Allah dan RasulNya, menampakkan sisi kemenarikan dari diri perempuan kepada lelaki yang bukan muhrim, ini tidak memperhitungkan adanya kenyataan lain yang sifatnya sosiokultural, seperti dalam dunia karir dan pekerjaan, dunia interaksi sosial modern, dan dunia pendidikan, misalnya.

Mufti Saudi Abd Al-Aziz Alu As-Syaikh mengikuti narasi fatwa diatas, pun turut menyatakan bahwa "mengemudi kendaraan terkadang menyebabkan terbukanya pintupintu keburukan, dan tidak terukur dengan jelas batasan-batasannya. Maka kita seharusnya tidak menetapkan masalah ini karena ini adalah masalah yang berbahaya, menjerumus kepada keburukankeburukan...." Demikian

juga Abdullah Al- Muni' salah satu anggota Hai'ah mengatakan: "Sesungguhnya dilarangnya perempuan mengemudi kendaraan merupakan pemuliaan dari negara terhadapnya, dan menjaga kesucian dan orisinalitasnya" (aljazeera.net, 2017).

Bahkan kajian fikih mengenai kasus ini dalam pandangan Dr. Abd Al-Aziz ibn Fauzan Al-Fauzan, salah satu otoritas keagamaan di Saudi Arabia, di salah satu laman Al-Multaqa Al-Fiqhi, dimana kajian tersebut memuat beberapa pertimbangan perihal perempuan berkarir dan bersosialisasi di tengah 
kehidupan sosial, namun berakhir dengan menguatkan fatwa yang berlaku, yakni perempuan dilarang mengemudi. Jikapun perempuan pada akhirnya terpaksa harus mengemudikan kendaraan sendiri, "ia mengemudikannya dengan memakai jilbab yang syar'i dan komplit (menurut undang-undang setempat) serta bertakwa kepada Allah Swt" (fiqhislammessage.com, 2017).

\section{Dibolehkannya Perempuan Mengemudikan Kendaraan}

Kemudian setelah puluhan tahun lamanya fatwa tersebut bertahan demi menjaga eksistensi kaum perempuan Saudi Arabia, pada 26 September 2017, Raja Salman ibn Abd Al-Aziz mengeluarkan keputusan agar perempuan diberi hak mengemudikan mobil sendiri, meskipun keputusan ini berlaku efektif pada bulan Juni tahun 2018. Raja Salman mengirimkan ultimatumnya kepada Menteri Dalam Negeri, yang diantara penggalan kalimatnya: "Menunjuk kepada halhal negatif dari tidak diperkenankannya perempuan mengemudi kendaraan, dan hal-hal positif dari diperbolehkannya mengemudi kepadanya, disertai dengan implementasi atura-aturan legal (syar'i) dan menegakannya, sebagaimana menunjuk kepada pendapat mayoritas anggota Hai'ah Kibar Ulama mengenai status mengemudikan kendaraan bagi perempuan, bahwa hukum syara' terhadap persoalan (mengemudinya perempuan) tersebut pada dasarnya adalah boleh. Citra pihak yang bersikap diam atas hal itu, dulunya berpegang pada ungkapanungkapan yang berkaitan dengan sad adz-dzarai' yang sifanya relatif, yang belum sampai kepada level pasti, juga mendekati pasti. Mereka juga tidak menemukan adanya larangan dari dibolehkannya wanita mengemudi kendaraan, (selama masih) dalam naungan penerapan jaminan-jaminan legal (syar'i) dan perundangan yang seharusnya..." Raja juga menjamin adanya undang -undang yang menjadi payung hukum dari kebolehan wanita mengemudi (Aljazeera.net, 2017).

Ungkapan Raja tentu sangat eksplisit bertentangan dengan fatwa yang melarang, dimana perempuan dilarang mengemudi disebabkan timbulnya hal-hal negatif dan membahayakan eksistensi perempuan terkait dirinya, agamanya dan keluarganya. Sementara pada keputusan ini, Raja justru membolehkan perempuan menyetir karena melihat adanya hal-hal positif dari kebolehan ini, 
dan timbulnya hal-hal negatif jika tidak segera diperbolehkan. Bahkan Raja menyebutkan Hai'ah Kibar al-Ulama' sebagai salah satu rujukan dalam pembolehan ini, dimana menurut Raja, pembolehan ini berdasarkan mayoritas anggota Hai'ah.

Bagaimana jawaban Hai'ah Kibar al-Ulama'?

Hai'ah Kibar al-Ulama' membenarkan titah Raja, dan menyatakan bahwa keputusan Raja Salman ini menjadi tolak ukur kemaslahatan dan bahaya. Menurut Lembaga ini, segenap ulama' syari'ah menetapkan bahwa tindakan seorang pemimpin terhadap rakyatnya adalah berpijak pada kemaslahatan. Sehingga tujuan dari ijtihad sang pemimpin adalah merealisasikan kemaslahatan secara total, dan menolak keru- sakan dan meminimalisirnya. Ber- dasarkanpada prinsip ini, maka sang pemimpin dalam setiap keputusannya berhak memilih mana yang lebih maslahat, lebih bermanfaat dan mudah.

Para anggota Hai'ah Kibar alUlama' menilai keputusan hukum berkaitan dengan pembolehan ini adalah berdasarkan kemaslahatan atau kerusakan yang terjadi. Sehingga pada kasus pembolehan ini, Raja melandaskannya pada dua standar tersebut, sebagaimana tersebutkan dalam pernyataannya itu. Menurut mereka, Raja jelas telah menemukan adanya bahaya yang terjadi bila wanita masih dilarang mengemudi kendaraan, dan mempertimbangkan keputusan para ulama' bahwa tidak ada larangan yang terang bagi wanita mengemudi kendaraan selama berada dibawah penerapan jaminan-jaminan syar'i dan perundang-undangan yang menjaga kehormatan perempuan (m.aawsat.com, 2017).

Selain kemaslahatan ditemukan di dalam prinsip-prinsip syari'ah, kemaslahatan juga ditemukan di dalam visi atau pandangan manusia, dimana visi tersebut dibangun untuk merealisasikan kemaslahatan masyarakat bersama, padahal tidak ada dalil yang sharih yang menyuruhnya. Ini yang kemudian dalam sudut pandang lain dari maqashid diungkapkan sebagai "kemaslahatan adalah syari'ah", almaslahah syari'ah (Ahmad Ar Raisuni, 2000: 31). Beberapa kaidah hukum yang lahir dari sudut pandang ini antara lain: al-maslahah al-mursalah, al-istihsan, al-'urf, alistidlal, dan beberapa kaidah fikih yang berbunyi:
Al-ashlu fi al-manafi' al-hill, wa fi al-madharr al-man'u (Pada dasarnya, hal-hal yang bermanfaat adalah halal, dan 
hal-hal yang berbahaya adalah dilarang).

- La dharara wa la dhirara (Tidak boleh membahayakan diri sendiri dan membahayakan orang lain).

- At-tasharrufu 'ala ar-ra'iyyah manuth bi al-maslahah (Memutuskan tindakan kepada rakyat adalah terjamin oleh kemaslahatan), dan sepertinya ini yang paling tepat untuk menilai keputusan Raja Salman. Maka ketika Hai'ah Kibar alUlama' telah mempercayakan keputusan diperbolehkannya wanita mengemudi kendaraan kepada Raja, tanpa menyebutkan komentar lebih lanjut berkaitan dengan dalil-dalil dari nash Alqur'an, Hadis Nabi Saw., atau mengutip pendapat ulama', yang perlu kita pahami adalah apa kirakira kemaslahatan yang tertangkap dalam visi sang Raja itu?

\section{Membaca Kemaslahatan dalam}

\section{Visi Raja}

\section{Bidang Politik}

Raja Salman selaku pemegang otoritas struktural tertinggi Saudi telah melakukan sejarah besar dalam kebijakan politik dalam negeri. Terlihat dalam keputusan kerajaan mengenai diperbolehkannya perempuan Saudi mengemudi yang secara otomatis telah men-nasakh hukum asal tentang tidak diperbolehkannya perempuan Saudi mengemudi. Melalui keputusan ini, Kerajaan Saudi khususnya Raja Salman memandang bahwasanya sudah saatnya bagi perempuan Saudi ikut berperan dalam ruang publik Saudi. Baik dari sisi politik, ekonomi, sosial dan pendidikan.

Seperti yang sudah dipaparkan di atasb ahwa kemaslahatan dalam suatu putusan hukum menjadi satu hal yang sangat diperhatikan. Demikian juga dalam fatwa hukum diperbolehkannya perempuan Saudi mengemudi, kemaslahatan menjadi ukuran yang dipakai dalam putusan hukum ini. Raja Salman memandang bahwa kemaslahatan putusan hukum ini lebih besar dibandingkan dengan bahayanya. Karena dengan disahkannya putusan hukum ini, bertujuan untuk meningkatkan potensi perempuan Saudi dalam mendongkrak pamor Saudi sebagai negara yang dinamis, karena selama ini Saudi dikenal dengan negara yang stagnan dan menekan hak-hak kaum perempuan.

Dari sudut pandang kemaslahatan politis, Raja Salman bermaksud membuka kran-kran keterlibatan langsung perempuan dalam percaturan perpolitikan 
Saudi. Dengan adanya keterlibatan perempuan ini, dipastikan akan muncul warna yang baru dalam madzhab-madzhab politik yang ada, dan tentu saja kaum perempuan didalam struktur pemerintahan nantinya mampu menjadi sayap kaum perempuan, sebab perempuan Saudi memiliki potensi untuk mengisi kekosongan ini. Juga, perlu menjadi catatan bahwa putusan hukum ini secara kemaslahatan politik dapat menjadi power (kekuatan) guna mendulang dukungan perempuan terhadap kerajaan.

Ketika dukungan kepada kerajaan semakin kuat, maka kemaslahatan akan dapat dirasakan. seperti; berkurangnya potensi konflik internal (perang saudara), saving (pengamanan) kekuasaan kerajaan dan pemenuhan hak-hak perempuan yang selama ini dinilai masih timpang. Putusan hukum ini diharapkan juga dapat mendongkrak popularitas politik kerajaan khususnya Raja Salman sebagai aktor yang telah me-nasakh fatwa/ putusan hukum sebelumnya.

\section{Bidang Ekonomi}

Kemaslahatan ekonomi negara juga menjadi pertimbangan yang kuat dalam visi Raja Salman dalam keputusan ini. Saudi adalah salah satu negara penghasil minyak terbesar di dunia. Sehingga sudah mafhum bahwa Saudi sangat mengandalkan minyak sebagai devisa negara untuk menopang perekonomiannya. Tetapi semenjak harga minyak dunia turun secara drastis, pemerintahan Saudi mau tidak mau harus mencari solusi lain guna menutup anggaran belanja negara yang membengkak. Terbukti lawatan Raja Salman ke berbagai negara Asia termasuk Indonesia Maret 2017 lalu, membawa misi untuk menguatkan perekonomian Saudi untuk 10 tahun kedepan tanpa bergantung dengan minyak (kompas.com, 2017).

Selain itu, Saudi juga termasuk negara yang beberapa tahun ini meningkatkan belanja negaranya dalam bidang keamanan dan militer. Hal ini misalnya bisa dilacak dari belanja kelengkapan persenjataan, dimana pada tahun 2014 negara tersebut menghabiskan USD 80 juta; jumlah yang belum dicapai ditahuntahun sebelumnya (shorouknews. com, 2017). Kemudian pada tahun 2015 menghabiskan sebanyak SAR 20 milyar (USD 5,3 milyar), disusul tahun 2016 meningkat lagi menjadi SAR 213 milyar, dan jumlah ini menempati sebanyak $25 \%$ dari keseluruhan anggaran belanja (reuters.com, 2015). Belanja negara dalam bidang ini 
kemudian tidak meraup hasil yang produktif, sehingga pemerintah Saudi mengalami defisit, dan harus menutupinya.

Maka benarlah pengamatan banyak ahli, bahwa ekonomi Saudi Arabia telah kedodoran akibat anjloknya harga minyak hingga kisaran 30 dollar per barel (bbc.com, 2016), biaya perang yang tinggi, dan petualangannya di kawasan maupun dunia Islam. Dan persoalan ini menjadi informasi yang hanya bisa ditangkap melalui pengamatan yang jeli, sebab tentu saja tidak diinformasikan secara resmi oleh internal Kerajaan (geotimes.com, 2017).

Dengan putusan hukum diperbolehkannya perempuan Saudi ini, diharapkan dapat mem- buka kran -kran perekonomian baru Saudi. Sebab putusan hukum ini merupakan jembatan bagi perempuan untuk ber -elaborasi dengan pria secara lebih produktif, khususnya setelah mendapatkan akses didalam pemerintahan. Karena dengan akses ini diharapkan perempuan memiliki potensi yang lebih dalam mendongkrak perekonomian negara. Tidak hanya kebahagiaan dan suka cita perempuan Saudi beberapa saat setelah keputusan ini turun, namun kran-kran ekonomi di bidang lain pun mulai terbuka. Tidak hanya kemudian sebanyak $80 \%$ perempuan Saudi berbondong-berbondong mengajukan pembuatan surat izin mengemudi, namun kunjungan kaum perempuan di pasar kendaraan roda empat mulai meningkat. Hal ini menjadi tanda positif tersendiri, setelah jumlah penjualan mobil menurun menjadi 530 buah di tahun 2016, dari jumlah 685 buah di tahun 2015. Perhitungan inilah barangkali yang juga sedang dibentuk dalam program "visi 2030" yang digagas Saudi Arabia sejak 2015 (rt.com, 2017).

Potensi kaum perempuan ini menjadi ukuran kemaslahatan yang dimenangkan oleh Raja, dibanding ke-mafsadahan -nya. Dan dalam bidang ekonomi, tidak hanya potensi dari pasar kendaraan, potensi peningkatan pariwisata dan dunia karir pun bisa menjadi bentuk kemaslahatan yang menjanjikan bagi kemajuan Saudi Arabia dalam visi Raja.

\section{Kesimpulan}

Peristiwa terjadinya perubahan fatwa hukum di Saudi Arabia, dari dilarangnya perempuan mengemudi kendaraan menjadi dibolehkan, bertumpu kepada alasan-alasan yang mengarah kepada meraih kemaslahatan dan menolak bahaya 
dan kerusakan. Alasan-alasan tersebut secara terang dinyatakan dalam klausul-klausul produk hukumnya.

Hanya saja, ada perbedaan orientasi dari dua arah produk hukum tersebut. Orientasi dari dilarangnya perempuan mengemudi bisa diungkapkan sebagai assyari'ah maslahah; syari'ah adalah kemaslahatan, dimana larangan mengemudi bersumber dari dalildalil Al-qur'an dan Hadis Nabi Saw. yang secara terang menungkapkan bahayanya kaum perempuan beraktifitas di luar rumah, dan menyuruh mereka tetap di dalam rumah, dan inilah kemaslahatannya.

Adapun orientasi dari dibolehkannya- kaum perempuan mengemudi- kendaraan bisa diungkapkan- sebagai al-maslahah syari'ah; kemaslahatan merupakan syari'ah, dimana keputusan Raja akan kebolehan kaum wanita mengemudi yang - menjadi sumber fatwa pembolehan tersebut berdasarkan kepada dapat diraihnya kemaslahatan-kemaslahatan khusus yang terdapat dalam pandangan visi Raja sebagai pemerintah, dan menolak kerusakan yang juga telah terbacadalam visinya. Bentukbentuk visi terbut tergambarkan dalam kemaslahatan tata negara dan stabilitasnya, baik yang bersifat politik maupun ekonomi.

\section{Daftar Pustaka}

\section{Buku dan Jurnal:}

Al-Haramain, Imam, Al-Waraqat, Riyadh, Dar Ash-Shomai'i, 1996

Wahab Khalaf, Abdul, Ushul Fiqh, Kairo, Maktabah Ad-Da'wah Al-Islamiyah, 1956

Tarmizi, Pembaruan Hukum Islam di Indonesia; Keberadaannya dalam Perundang-undangan, Jurnal Istinbath, Vol. 9, No. II, November 2012

Hazairin, Tujuh Serangkai Tentang Hukum, Jakarta: Tintamas, 1974

Shidiq, Ghofar, Teori Maqashid asysyari'ah Dalam Hukum Islam, Jurnal Sultan Agung, Vol. XLIV No. 118, Agustus 2009

Sa'id Ramadhan Al-buthi, Muhammad, Dhawabith AlMaslahah fi As-Syari'ah AlIslamiyyah, Damaskus: Dar Al-Fikr, 2014

Ar-Raisuni , Ahmad dan Jamal Barout, Muhammad, AlIjtihad: An-Nash, Al-Waqi, Al-Maslahah, Damaskus: Dar Al-Fikr, 2000 
Al-Qardhawi, Yusuf, Fiqh Praktis Bagi Kehidupan Modern, Kairo, Maktabah Wahbah, 1999 Syatibi, Imam, Al-Muwafaqat $f i$ Ushul Asy-Syari'ah, Beirut, Dar al-Kutub al-Islamiyyah, Juz I

Jaya Bakri, Asafri, Konsep Maqashid Asy-Syari'ah menurut Asy-Syatibi, Jakarta, Rajawali Press, 1996

Abu Zahrah, Muhammad, Ushul Fiqh, Mesir, Dar- Al-fikr, Al'Arabi, 1958

\section{Website:}

Saudi Arabia Country Profile, http:// www.bbc.com/news/worldmiddle-east-14702705, diakses 1 Oktober 2017

Lajnah ad-Daaimah Lil Buhuuts wa alFataawa Lihat; Hai'ah Kibar alUlama' as-Su'udiyyah, https:// ar.wikipedia.org/wiki/\%D9\%87\% D9\%8A\%D8\%A6\%D8\%A9_\%D 9\%83\%D8\%A8\%D8\%A7\%D8\% B1_\%D8\%A7\%D9\%84\%D8\%B9 \%D9\%84\%D9\%85\%D8\%A7\%D 8\%A1_\%D8\%A7\%D9\%84\%D8 $\% \mathrm{~B} 3 \% \mathrm{D} 8 \% \mathrm{~B} 9 \% \mathrm{D} 9 \% 88 \% \mathrm{D} 8 \% \mathrm{~A}$ F\%D9\%8A\%D8\%A9, diakses 1 Oktober 2017

Qiyadah Al-Mar'ah li As-Sayyarat bi As-Su'udiyyah, http://aljazeera. net / news/ reportsandin terviews/2 017/9/27/

$$
\begin{aligned}
& \text { قدايد ق-ةأرلم ا - سـ لل ت اراي-عـد الاب }
\end{aligned}
$$

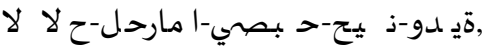
diakses pada 30 September 2017 http://www.alifta.net /Search /

ResultDetails.as px? lang uagena $\mathrm{m}$ e=id\&lang $=$ i d \&vie $\mathrm{w}=\mathrm{re}$ sult\&fat wa $\mathrm{Nu} m=\&$ FatwaN umID $=\& I D=6529 \&$ searchSco pe $=3 \&$ Search Scop e evels1= \& Search ScopeLev els2 $=\&$ highLight $=1 \&$ SearchT ype $=$ ex act \& Search Moesar $=$ false \& bookID $=\&$ Lef $\mathrm{tVal}=0 \&$ RightVal $=0 \&$ simple $=\& S e$ archC ri te ria=allw ords\& $P$ agePath $=$ \&site Section $=1 \&$ s earchk eyword=10 4117107 $\begin{array}{lllllll}1171 & 09 & 03 & 2 & 109 & 1011 & 10121\end{array}$ 1011161051140321109711 010511 6097\#firs tKeyWo rdFound. Teks $\mathrm{t}$ ersebut diterjemah ke laman Fatwa Saudi berbahasa Indonesia, fatwa nomor 6412, dari laman resmi Abd Al-'Aziz ibn Baz: http://www.binbaz.org.sa/ article/339. keduanya diakses pada 29 September 2017

Madzhib Al-Fuqaha Al-Mu'ashirin $f i$ Hukm Qiyadah Al-Mar'ah li AsSayyarah, pada laman http:// www.fiqh. islam message. com/ New Details .aspx? id=9246, diakses pada 29 September 2017 
Qiyadah Al-Mar'ah li As-Sayyarat bi As-Su'udiyyah, http://Aljazeera. net / news /reportsandinterviews

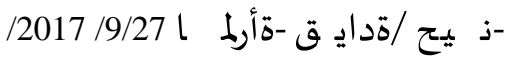

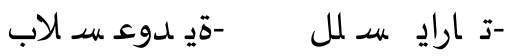
ح- diakses pada 30 September 2017. Selengkapnya ada pada siaran Televisi As-Su'udiyyah, direkam dalam Youtube dengan judul $\mathrm{Al}$ Malik Salman Yashduru Amrahu bis Samah li Al-Mar'ah Biqiyadah As-Sayyarah, diupload 26 September 2017, diakses pada 30 September 2017

Kibar Ulama: Qiyadah Al-Mar'ah li As-Sayyarat la Yuharrimuha Ahad, dalam laman As-Syarq Al-Ausath di http://m.aawsat. com /home/article/1035681/

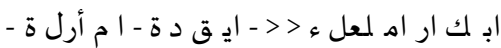

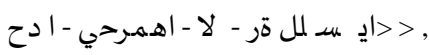

diakses pada tanggal 30

September 2017

Sakina Rakhma Diah Setiawan, Mulai 2020 Arab Saudi Tidak Peduli Lagi dengan Harga Minyak, http://ekonomi .kompas .com /read /2017/05 /19 /101500526/mulai.2020 .arab.saudi . tak.peduli .lagi. dengan.harga .minyak, diakses 19 Agustus 2017
Fahmi Huwaidi, Nahnu Nantahir wa Hum Yarbahun, http://www. shorouknews .com /columns / view.aspx ? cdate $=22042015$ $\& \mathrm{id}=\mathrm{e} 7574 \mathrm{a} 0 \mathrm{e}-\mathrm{c} 135-4 \mathrm{cf} 7$ b90e - 42c65 2afe7b5, diakses pada 30 September 2017

http://www.reuters.com /article / ussaudi- budget- security / saudisecurity- spending- rises-5-3billion-in-2015 -minister idUSKBNOUB1 9F20151228 , diakses pada 1 Oktober 2017

Ibnu Burdah, Jebolnya Bendungan Wahabisme, http://www. geotimes .co.id /kolom / internasional/ jebolnya bendungan - wahabisme /, diakses pada 18 Oktober 2017. http://www.arabic.rt.com /business

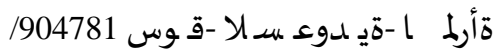

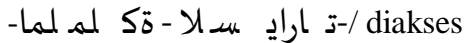

